\title{
PROFIL PEMECAHAN MASALAH MATEMATIKA SISWA SMP DENGAN KECERDASAN INTERPERSONAL DITINJAU BERDASARKAN GENDER
}

\author{
Agung Wicaksono \\ Program Studi Tadris Matematika, FTIK, Institut Agama Islam Negeri Palu \\ Agung_wicaksono@iainpalu.ac.id
}

\begin{abstract}
ABSTRAK
Penelitian ini adalah penelitian kualitatif yang bertujuan untuk mendapatkan gambaran profil siswa yang memecahkan masalah matematika kelas IX SMP dengan kecerdasan interpersonal berdasarkan perbedaan gender pada fase Polya. Subjek penelitian ini adalah siswa kelas IX SMP yang memiliki kecerdasan interpersonal berdasarkan perbedaan gender. Penelitian ini dilakukan di SMP Kota Palu, Sulawesi Tengah. Berdasarkan analisis data dapat disimpulkan bahwa siswa laki-laki yang memiliki kecerdasan interpersonal dapat melakukan semua tahap pemecahan masalah matematika, yaitu memahami masalah, membuat rencana, melaksanakan rencana kami, dan melihat kembali solusi yang lengkap dengan kecenderungan untuk membangun interaksi dengan orang lain untuk dengan mudah memahami masalah. Sementara siswa perempuan yang memiliki kecerdasan interpersonal saat melakukan beberapa tahap pemecahan masalah matematika membutuhkan bantuan terlalu banyak, yaitu memahami masalah dan membuat rencana. Adapun tahap melaksanakan rencana kami, dan melihat kembali solusi yang telah diselesaikan siswa perempuan dengan penuh kepercayaan.
\end{abstract}

Kata kunci: profil, penyelesaian masalah, kecerdasan interpersonal, gender.

\section{ABSTRACT}

This study is a qualitative research that aims to get a description of the profile of students mathematical problem solving grade IX SMP with interpersonal intelligence based on gender differences on Polya phase. The subjects of this study were students at grade IX of Junior High School who had a interpersonal intelligence based on gender differences. This study was conducted at the Junior High School in Palu, Central Sulawesi. Based on data analysis can be concluded that male students who have interpersonal intelligence can do all stages problem solving of mathematics, that is understand the problem, make a plan, carry out our plan, and look back at the completed solution with tendencies to build up interaction with other people to easily understand the problems. While female students who have interpersonal intelligence while do some stage problem solving of mathematics need help too much, that is understand the problem and make a plan. As for the stages carry out our plan, and look back at the completed solution the female students do with full of confidences.

Keywords : profile, problem solving, interpersonal intelligence, gender.

\section{PENDAHULUAN}

Matematika adalah ilmu pengetahuan yang dipelajari sejak zaman dahulu hingga kini dan merupakan dasar perkembangan ilmu pengetahuan dan teknologi modern yang terjadi di dunia saat ini. Matematika merupakan disiplin ilmu yang mempunyai sifat khas, yakni berkenaan dengan ide-ide atau konsep-konsep abstrak yang tersusun secara hirarkis. 


\section{Koordinat Jurnal Pembelajaran Matematika dan Sains}

Vol. 1, No. 1, Juli 2020, Hal. 39-51

Belajar matematika bertujuan untuk melatih siswa tidak hanya terampil menggunakan konsep-konsep matematika dalam mengerjakan soal-soal matematika, tetapi dapat menggunakan matematika untuk memecahkan masalah yang dijumpai dalam kehidupan sehari-hari. Siswa perlu dibiasakan untuk memecahkan suatu masalah melalui belajar matematika di sekolah yang dilakukan dengan aktivitas pemecahan masalah.

Aktivitas pemecahan masalah merupakan bagian yang penting dalam pembelajaran matematika. National Council of Teacher of Mathematics (NCTM) menetapkan lima standar kemampuan matematis yang dimiliki oleh siswa, yaitu kemampuan pemecahan masalah, kemampuan komunikasi, kemampuan koneksi, kemampuan penalaran dan kemampuan representasi (Efendi, 2012). Hal ini berarti bahwa pemecahan masalah merupakan salah satu kemampuan yang penting dikembangkan dan harus dimiliki oleh siswa.

Pemecahan masalah dalam matematika adalah suatu aktivitas untuk mencari solusi dari soal matematika yang dihadapi, dengan melibatkan semua bekal pengetahuan (telah mempelajari konsepkonsep) dan bekal pengalaman (telah terlatih dan terbiasa menghadapi dan menyelesaikan soal). Tidak semua soal matematika akan menjadi masalah bagi siswa, suatu masalah sangat bergantung kepada individu dan waktu tertentu (Hudoyo, 2005). Soal matematika akan menjadi masalah, apabila soal itu menunjukkan adanya tantangan yang tidak dapat dipecahkan oleh prosedur rutin yang sudah diketahui oleh siswa. Oleh sebab itu, dapat terjadi suatu soal yang merupakan masalah bagi seorang siswa, akan tetapi menjadi soal biasa bagi siswa yang lain, karena siswa tersebut sudah mengetahui prosedur untuk menyelesaikannya.

Kegiatan belajar dan mengajar matematika seharusnya tidak disamakan dengan ilmu yang lain. Kegiatan belajar dan mengajar seharusnya disusun berdasarkan kemampuan dan karakteristik siswa, karena setiap siswa memahami dan menyerap pelajaran dengan berbeda-beda, ada yang cepat, sedang, ada pula yang sangat lambat (Uno, 2006). Oleh karena itu, setiap siswa memiliki karakteristik yang berbeda antara siswa yang satu dan yang lainnya dalam mempelajari materi di dalam kelas.

Salah satu karakteristik siswa yang perlu diperhatikan pada saat proses belajar mengajar adalah kecerdasan yang dimiliki siswa. Setiap orang setidaknya memiliki delapan jenis kecerdasan majemuk (multiple intelligences) yaitu kecerdasan linguistik, logika-matematika, visual-spasial, musikal, kinestetik, interpersonal, intrapersonal dan naturalistik, namun hanya beberapa yang dominan pada masing-masing individu (Yaumi, 2012). Kedelapan kecerdasan tersebut tidak tertutup kemungkinan akan terdapat pada siswa dalam kelas yang akan diajar oleh guru. Oleh karena itu pembelajaran di kelas, seorang guru harus bisa memahami karakteristik kecerdasan yang dimiliki oleh siswanya, karena dalam satu kelas setiap siswa memiliki kecerdasan yang berbeda-beda sehingga dibutuhkan cara mengajar yang berbeda-beda pula.

Delapan jenis kecerdasan majemuk tersebut, terdapat tiga jenis kecerdasan yang berkaitan langsung dengan belajar matematika dan pemecahan masalah matematika. Beberapa penelitian mengemukakan bahwa kecerdasan linguistik dan logika-matematika berkaitan erat dengan hasil belajar matematika (Hardiani, 2007) dan kecerdasan logika-matematika dan visual-spasial berkontribusi kuat terhadap prestasi belajar matematika (Jayantika, 2013). Belajar matematika membutuhkan kemampuan mengolah informasi (komputasi) dari system simbol pada ranah kognisi (Gardner, 2013). Lima jenis kecerdasan lainnya yaitu kecerdasan musikal, kinestetik, interpersonal, intrapersonal dan naturalistic tidak secara khusus dianggap sebagai kecerdasan dalam belajar matematika, namun selanjutnya Gardner menyatakan bahwa belajar matematika dapat menggunakan lima kecerdasan tersebut.

Jenis kecerdasan interpersonal dapat digunakan dalam belajar matematika. Kecerdasan interpersonal adalah kemampuan untuk memahami dan 


\section{Koordinat Jurnal Pembelajaran Matematika dan Sains Vol. 1, No. 1, Juli 2020, Hal. 39-51}

bekerjasama dengan orang lain (Amstrong, 2002). Kecerdasan interpersonal dapat digunakan dalam belajar matematika karena dalam proses pembelajaran matematika, siswa sering kali mengalami kesulitan dengan aktivitas belajarnya terutama dalam pemecahan masalah. Sebab terkadang siswa perlu lebih banyak berinteraksi dengan teman yang dianggap lebih pandai atau kepada guru untuk meminta bantuan dalam memecahkan suatu masalah atau siswa perlu suasana yang hening serta lebih suka seorang diri dalam memecahkan suatu masalah. Oleh karena itu perlu diketahui profil pemecahan masalah siswa dengan kecerdasan interpersonal sehingga mereka dapat diberi bantuan dalam belajar matematika terutama dalam aktivitas pemecahan masalah matematika.

Selain itu tingkat kemampuan pemecahan masalah tiap siswa terutama siswa laki-laki dan siswa perempuan berbeda tergantung dengan keterampilan dan tingkat intelegensi yang dimiliki. Menurut Krutetskii (dalam Wardani, 2014) mengungkapkan bahwa ketepatan, ketelitian, kecermatan, dan keseksamaan berpikir laki-laki mempunyai kemampuan matematika lebih baik daripada perempuan.

Sejalan dengan itu, Menurut American Psychological Association (dalam Nafi'an, 2011) mengemukakan berdasarkan analisis terbaru dari penelitian internasional kemampuan perempuan diseluruh dunia dalam matematika tidak lebih buruk daripada kemampuan laki-laki.

Perbedaan gender adalah perbedaan bawaan laki-laki dan perempuan yang dapat berubah setiap saat melalui upaya yang dilakukan. Gender ditentukan oleh sosial dan budaya setempat sedangkan seks adalah pembagian jenis kelamin yang ditentukan oleh Tuhan. Kognitif adalah salah satu aspek bawaan laki- laki dan perempuan yang dapat berubah dan berkembang setiap saat sebagaimana telah dijelaskan oleh Jean Peaget. Dengan demikian, aspek kognitif yang meliputi cara berpikir termasuk perbedaan gender.
Beberapa penelitian untuk menguji bagaimana perbedaan gender berkaitan dengan pembelajaran matematika, laki-laki dan perempuan dibandingkan dengan menggunakan variabel-variabel termasuk kemampuan bawaan, sikap, motivasi, bakat, dan kinerja (Goodchild \& Granholm, 2007). Beberapa peneliti percaya bahwa pengaruh faktor gender (pengaruh perbedaan laki-lakiperempuan) dalam matematika adalah karena adanya perbedaan biologis dalam otak anak laki-laki dan perempuan yang diketahui melalui observasi, bahwa anak perempuan, secara umum, lebih unggul dalam bidang bahasa dan menulis, sedangkan anak laki- laki lebih unggul dalam bidang matematika, karena kemampuan-kemampuan ruangnya yang lebih baik (Geary, Saults, Liu, 2000). Akibatnya, perbedaan gender dalam matematika cukup sulit diubah.

Berdasarkan uraian di atas, maka peneliti ingin mengungkapkan profil pemecahan masalah matematika siswa kelas IX SMP dengan kecerdasan interpersonal ditinjau berdasarkan gender. Pengungkapan profil pemecahan masalah didasarkan pada langkah pemecahan masalah oleh Polya yaitu: (a) memahami masalah; (b) merencanakan pemecahan masalah; (c) melaksanakan rencana pemecahan dan (d) memeriksa kembali hasil pekerjaan yang telah dibuat.

\section{METODE PENELITIAN}

Jenis penelitian ini adalah penelitian kualitatif dengan pendekatan deskriptif kualitatif. Penelitian ini mendeskripsikan profil pemecahan masalah matematika siswa Kelas IX SMP yang memiliki kecerdasan kecerdasan interpersonal ditinjau dari gender berdasarkan langkah-langkah Polya yakni mulai dari memahami masalah, menyusun rencana pemecahan, melaksanakan rencana pemecahan sampai memeriksa kembali hasil pekerjaan yang dibuat. Penelitian ini dilaksanakan di Sekolah Menengah Pertama (SMP) yang terletak di Kota Palu, Propinsi Sulawesi Tengah. Subjek dalam penelitian ini adalah siswa kelas IX SMPN 1 Palu yang 


\section{Koordinat Jurnal Pembelajaran Matematika dan Sains}

Vol. 1, No. 1, Juli 2020, Hal. 39-51

memiliki kecerdasan interpersonal. Proses dalam menentukan subjek pada penelitian ini melalui tes kecerdasan majemuk yang dikembangkan oleh Winarto (2010). Pada instrumen tersebut, disediakan 10 butir pernyataan tentang karakteristik dari masing-masing jenis kecerdasan, dan setiap pernyataan yang dipilih maka diberi skor 15 , sehingga diperoleh variasi skor antara 0 sampai 50 pada setiap kecerdasan. Cara mengetahui jenis kecerdasan dominan seseorang berdasarkan perolehan skor pada tes kecerdasan majemuk. Jenis kecerdasan majemuk dominan adalah jenis kecerdasan yang memperolah skor paling tinggi. Siswa yang telah memenuhi kriteria sebagai siswa yang memiliki kecerdasan interpersonal dominan, selanjutnya dipilih minimal masing-masing satu orang siswa secara acak. Apabila tidak mendapatkan data yang diinginkan dari subjek yang dipilih, maka akan diambil subjek yang lain dengan jenis kecerdasan yang sama.

Jenis data dalam penelitian ini adalah data kualitatif berupa data profil pemecahan masalah matematik subjek yang terdiri dari data profil pemahaman masalah matematika, penyusunan rencana pemecahan masalah matematika, pelaksanaan rencana pemecahan masalah matematika dan pemeriksaan kembali hasil pekerjaan yang telah dibuat siswa kelas IX SMP dengan kecerdasan interpersonal. Teknik yang dilakukan untuk memperoleh data dalam penelitian ini adalah tes tertulis, teknik wawancara mendalam (In dept interview) dan teknik observasi. Tes tertulis berisi masalah matematika yang harus diselesaikan oleh subjek penelitian. Wawancara mendalam ialah proses memperoleh keterangan dari subjek mengenai suatu masalah yang dihadapi dengan cara tanya jawab sambil bertatap muka antara pewawancara dengan responden, dengan atau tanpa menggunakan pedoman. Adapun observasi merupakan proses pengamatan perilaku yang dilakukan subjek penelitian untuk memperoleh data dari tingkah laku tersebut. Instrumen utama dalam penelitian ini yaitu peneliti sendiri, artinya bahwa peneliti melakukan pengumpulan data secara langsung dan tidak dapat digantikan oleh siapapun. Instrumen pendukung yang digunakan untuk menentukan subjek penelitian yaitu siswa SMP dengan kecerdasan interpersonal dominan adalah tes kecerdasan majemuk. Instrumen pendukung lain yang digunakan untuk mengeksplorasi profil pemecahan masalah matematika dari subjek yang terpilih adalah masalah matematika pada barisan dan deret yang berupa tes tertulis.

Data profil pemecahan masalah matematika siswa kelas IX SMP dengan kecerdasan interpesonal dianalisis dengan mengacu pada model analisis data dari Miles and Huberman (1992), dimana terdapat tiga langkah kegiatan anailis data yaitu: reduksi data, penyajian data dan penarikan kesimpulan.

Data hasil tes tertulis, hasil wawancara dan hasil observasi setelah memecahkan masalah dari masing-masing subjek, selanjutnya ditranskrip. Data yang tidak mendukung tujuan penelitian direduksi. Reduksi data dilakukan dengan cara membuat rangkuman inti, menyederhanakan data yang diperoleh dan membuang data yang tidak diperlukan. Selanjutnya data masing-masing subjek tersebut dikategorikan yaitu dengan mengelompokkan data yang saling berkaitan, misalnya data subjek dengan kecerdasan interpersonal laki laki pada saat memahami masalah.

Pengkodean dapat dilakukan agar mempermudah memahami pembacaan terhadap hasil observasi, jawaban tertulis dan transkrip wawancara. Arti beberapa singkatan yang muncul, P (peneliti), KIL adalah subjek dengan kecerdasan intrapersonal Laki-laki, KIP adalah subjek dengan kecerdasan interpersona Perempuanl, $\mathrm{M}_{1}$ adalah masalah matematika, $\mathrm{M}_{2}$ adalah masalah setara. Pemberian kode dilakukan sebagai berikut: dua digit pertama berupa dua huruf menyatakan kode subjek penelitian (KIL, KIP), dua digit berikutnya berupa huruf dan angka menyatakan masalah matematika $\left(\mathrm{M}_{1}\right.$ dan $\left.\mathrm{M}_{2}\right)$, sedangkan digit terakhir berupa angka menyatakan urutan pernyataan subjek.

Data yang disajikan adalah data hasil pekerjaan subjek KIL dan KIP, data hasil 


\section{Koordinat Jurnal Pembelajaran Matematika dan Sains Vol. 1, No. 1, Juli 2020, Hal. 39-51}

wawancara dan data hasil observasi yang telah direduksi. Sebelum data-data tersebut disajikan, terlebih dahulu dilakukan pemeriksaan data untuk menentukan kekonsistenan informasi yang diberikan subjek penelitian, sehingga diperoleh data yang kredibel (triangulasi data). Kredibilitas data dapat dilakukan dengan tiga cara yaitu: triangulasi sumber, triangulasi metode dan triangulasi waktu. Triangulasi yang digunakan dalam penelitian ini adalah triangulasi waktu, dimana subjek diuji dengan masalah matematika yang setara pada waktu yang berbeda. Apabila data yang diperoleh (data wawancara, hasil jawaban tertulis dan observasi) berbeda dengan sebelumnya, maka subjek diberikan tes kembali dengan masalah setara, sampai diperoleh data yang konsisten dari subjek tersebut. Apabila data subjek telah konsisten dari waktu yang berbeda dengan masalah yang setara, maka data yang diperoleh tersebut sudah kredibel. Data yang telah ditriangulasi dan kredibel, disajikan dalam bentuk naratif dan tabel. Penyajian data dalam bentuk naratif adalah data hasil wawancara dan data hasil observasi tentang perilaku subjek dalam memecahkan masalah, sedangkan data yang disajikan dalam bentuk tabel adalah data yang menggabungkan informasi yang tersusun secara padu dan mudah dicari.

Langkah terakhir dalam analisis data pada penelitian ini adalah penarikan kesimpulan. Kesimpulan dapat diambil apabila data mengenai profil pemecahan masalah matematika subjek yang disajikan telah kredibel. Kesimpulan dapat diambil berdasarkan data yang tersaji dan pengungkapannya didasarkan pada langkahlangkah pemecahan masalah Polya

\section{HASIL PENELITIAN}

Hasil pengelompokkan siswa pada penelitian menunjukkan bahwa dari seratus lima puluh siswa kelas IX SMPN 1 Palu yang mengikuti tes kecerdasan majemuk diperoleh data interpersonal dominan sebanyak sepuluh orang. Diantara sepuluh siswa yang memiliki kecerdasan interpersonal dominan berdasarkan tes kecerdasan majemuk yang dilakukan peneliti, dipilih secara acak masing-masing 1 (satu) orang sebagai subjek berjenis kelamin laki-laki dan 1 (satu) orang sebagai subjek berjenis kelamin perempuan.. Kedua subjek tersebut diberi inisial KIP yaitu subjek dengan kecerdasan intepersonal dominan yang berjenis kelamin perempuan dan KIL yaitu subjek dengan kecerdasan interpersonal dominan yang berjenis kelamin laki-laki.

Selanjutnya setiap subjek mengerjakan M1. Untuk menguji kredibilitas data, peneliti melakukan triangulasi waktu yaitu memberikan soal yang setara dengan M1 yang diberi simbol M2 pada setiap subjek di waktu yang berbeda. Hasil triangulasi menunjukkan ada konsistensi jawaban subjek dalam menyelesaikan M1 dan M2, sehingga data setiap subjek dalam mengerjakan M1 dikatakan kredibel. Oleh karena data setiap subjek kredibel maka profil pemecahan masalah setiap subjek yang dianalisis adalah data pemecahan M1.

\section{A. Hasil Analisis Data profil pemecahan}

$M_{1}$ dengan subjek kecerdasan interpersonal laki-laki (KIL)

1) Hasil analisis data profil pemahaman $M_{1}$

KIL membaca M1 hanya sekali dengan suara keras dengan tujuan untuk membantunya memahami masalah agar cepat paham dan tidak bosan karena kurang bergairah jika bekerja seorang diri. KIL dapat mengidentifikasi informasi apa yang diketahui pada $\mathrm{M}_{1}$ dengan sering bertanya untuk mengantarkan dia memahami $\mathrm{M}_{1}$. Hal ini terlihat sebab KIL dapat menuliskan apa yang diketahui dan apa yang akan dicari dari soal yang diberikan.

Kutipan 1.

$$
\begin{aligned}
& \text { P : Berapa kali kamu membaca } \\
& \text { soal sampai paham? } \\
& \text { KIL : Hanya sekali. } \\
& \mathrm{P} \text { : Kenapa bersuara saat }
\end{aligned}
$$




\section{Koordinat Jurnal Pembelajaran Matematika dan Sains}

Vol. 1, No. 1, Juli 2020, Hal. 39-51

KIL : Biar cepat paham dan tidak bosan pak. Setalah saya baca dan bertanya tentang jumlah kursi dan bedanya, saya mulai paham apa yang diketahui dari soal ini pak .

P : Iya nak,, Saat membaca denga suara keras tadi, apa yang terlintas dalam pikiranmu?

KIL : Yang saya pikit Pokoknya dari barisan kursi yang diketahui ini bisa kita tau jumlah kursi yang ada di dalam ruangan. Walaupun rumusannya belum terlalu saya ingat pak

P : Bagaimana cara kamu menentukan yang diketahui ?

KIL : Ini di soal dibilang bahwa ada 15 barisan kursi dan jumlah barisan pertama itu 23. Tapi saya masih ragu barisan kedua itu berapa kursi, sama semuakah sampai barisan terakhir pak? Atau bagaimana? Tapi disoal bilang beda setiap barisnya.

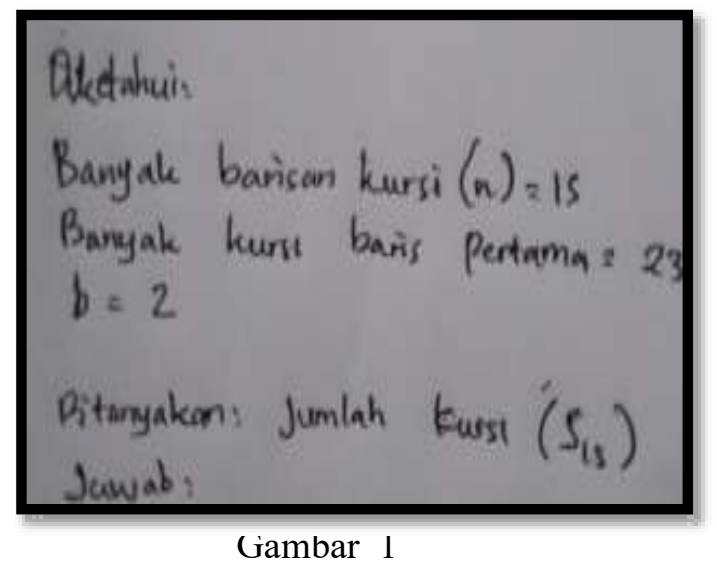

SIL lebih sering mengungkapkan secara lisan hal-hal yang dia pahami. Pada gambar 1.1 merupakan bukti pemahaman SIL baik ditandai dengan KIL mampu menuliskan hal-hal yang dia ketahui dan ditanyakan dalam soal. Gerakan tubuhnya pun Nampak begitu aktif bergerak ketika ada sesuatu yang tidak dipahami dan dia ingin bertanya.

2) Hasil analisis data profil penyusunan rencana pemecahan $\mathrm{M}_{1}$

KIL memiliki sifat tidak sabar dan tergesa-gesa (gelisah) pada saat mencari ide memecahkan $\mathrm{M}_{1}$, pada akhirnya KIL mendapat ide rencana untuk memecahkan $\mathrm{M}_{1}$ berdasarkan informasi yang diperolehnya melalui bertanya. KIL tampak gelisah dalam merencanakan penyelesaian $\mathrm{M}_{1}$ karena malas menulis jawaban dengan lengkap dan lebih menyukai cara lisan. KIL dalam menyusun rencana pemecahan $\mathrm{M}_{1}$ menggunakan cara konvensional yakni dengan mengalikan angka-angka yang ia ketahui dari soal. Dan pada akhirnya KIL dapat menyusun rencana pemecahan ditandai dengan KIL rumus yang telah dibuat.

Kutipan 2.

P : Mengapa tadi kamu seperti tidak tenang, terus menerus gelisah

KIL : saya malas menulis jawaban dengan cepat pak makanya gelisah, tidak apa-apa kan pak?

P : Iyaaa bisa, jadi bagaimana cara penyelesainnya.

KIL : Pertama saya mau kalikan satu-satu saja barisannya pak karena rumusnya agak saya lupa. Yang saya ingat $S_{n}=$ 


\section{Koordinat Jurnal Pembelajaran Matematika dan Sains}

Vol. 1, No. 1, Juli 2020, Hal. 39-51

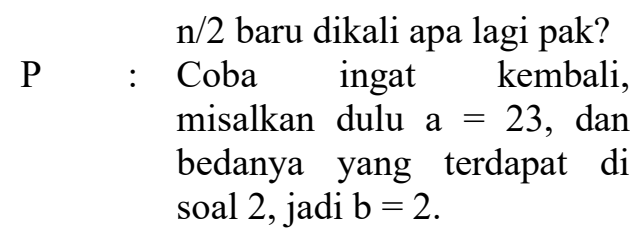

KIL : Tunggu pak, ku ingat-ingat. Pokoknya di kalikan a dan b itu pak. Tapi seperti ada lagi $2 \mathrm{a}$ atau n-1 itu. Masih saya coba ingat pak. Tapi betulkan pak ada dikali seperti itu?

3) Hasil analisis data profil pelaksanakan rencana pemecahan $\mathrm{M}_{1}$

KIL melaksanakan apa yang telah direncanakan, yakni menggunakan rumus yang telah ia susun sehingga diperoleh solusi dari masalah $\mathrm{M}_{1}$ yaitu 555. KIL melaksanakan apa yang telah direncanakan dengan gelisah dan agak terburu-buru serta lebih menyukai penyampaian secara lisan dibanding secara tertulis. KIL tampak keliatan gelisah saat melaksanakan apa yang telah direncanakan dalam menyelesaikan masalah $\mathrm{M}_{1}$ karena malas menulis dan lebih menyukai penyampaian lisan yang membuat dirinya bersemangat dalam meyelesaikan masalah. Waktu yang diperlukan KIL dalam melaksanakan apa yang telah direncanakan agak lama karena seringkali mengajukan pertanyaan untuk membantunya menemukan solusi dari M1 dan tidak memperhatikan waktu, berikut ini cuplikan hasil pekerjaan KIL.

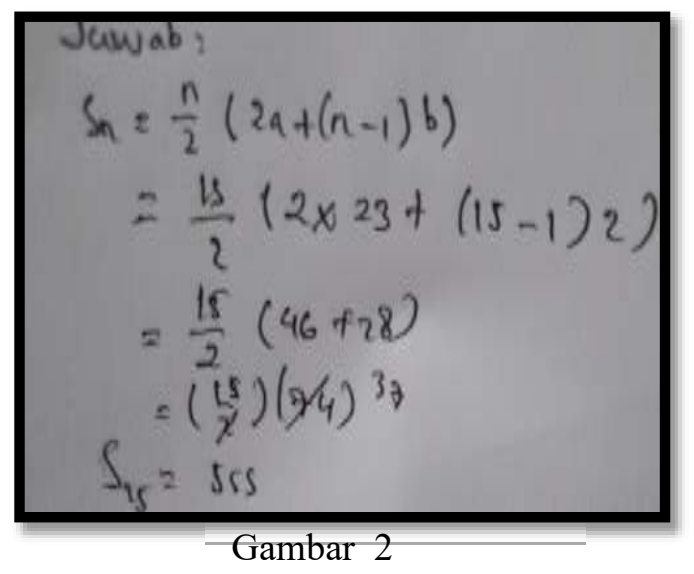

4) Hasil analisis data profil pemeriksaan kembali hasil pekerjaan untuk $\mathrm{M}_{1}$

KIL melakukan pemeriksaan kembali pada hasil pekerjaannya dengan baik ditandai dengan adanya jawaban akhir yang menjawab pertanyaan dari soal. Barikut kutipan dan cuplikan hasil pekerjaan KIL.

\section{Kutipan 4}
P : Apakah kamu sudah yakin dengan hasil jawabanmu?
KIL : \{melihat lembar jawaban\} sudah pak. Saya sudah kerja sesuai dengan yang diajarkan. Dan sudah hitung ulang-ulang juga pak.
P : Jadi, kamu tidak mengecek hasil pekerjaanmu lagi?
KIL : (sambil tersenyum)Tidak perlu pak, saya sudah yakin benar.




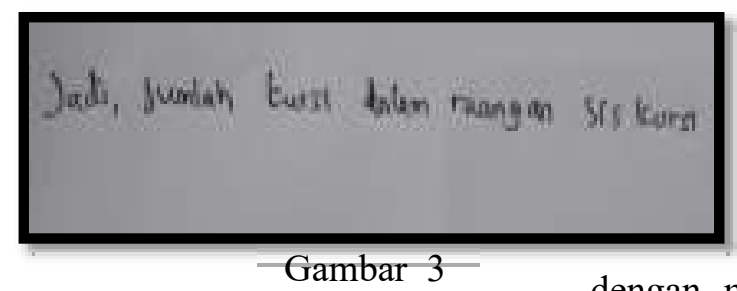

\section{B. Hasil Analisis Data profil pemecahan} $M_{1}$ dengan subjek kecerdasan interpersonal Perempuan (KIP)

1) Hasil analisis data profil pemahaman $M_{1}$ KIP membaca $M_{1}$ beberapa kali dengan sesekali suaranya terdengar cukup keras dengan tujuan untuk membantunya memahami masalah agar cepat paham. KIP dapat mengidentifikasi informasi apa yang diketahui pada $\mathrm{M}_{1}$ dengan sering bertanya untuk membantu dia agar cepat memahami $\mathrm{M}_{1}$. KIP dapat memahami dengan baik ditandai dengan menuliskan apa yang diketahui dan apa yang akan dicari dari soal yang diberikan.

\section{Kutipan 5}

$$
\begin{array}{ll}
\mathrm{P} & : \text { Berapa kali kamu membaca } \\
& \text { soal sampai paham ? } \\
\mathrm{KIP}: & \text { 3-4 kali pak } \\
\mathrm{P}: \text { Bapak sempat mendengarkan } & \text { saat membaca soal tadi. } \\
& \begin{array}{l}
\text { Apakah ada tujuannya? } \\
\mathrm{KIP}: \text { Saya merasa lebih cepat } \\
\text { paham saat membaca soal }
\end{array}
\end{array}
$$

dengan mengeluarkan suara pak disbanding membacanya dalam hati. .

P : Iya nak,, Saat membaca denga suara keras tadi, apa yang terlintas dalam pikiranmu?

KIP : Yang muncul dipikiranku kondisi ruangan itu pak, dengan barisan-barisan kursi yang mau di cari jumlahnya. Tapi saya tahu ada rumusnya hanya saja saya lupa susunan rumusnya pak, yang pastinya diperlukan berapa jumlah suatu barisan dan pasti ada bedanya pak. Betulkan pak?.

P : Bagaimana cara kamu menentukan yang diketahui ?

KIP : $\mathrm{a}=23$ buah, dan di soal dibilang bedanya tiap baris itu 2. Lebih banyak kursi dibarisan depan pak.

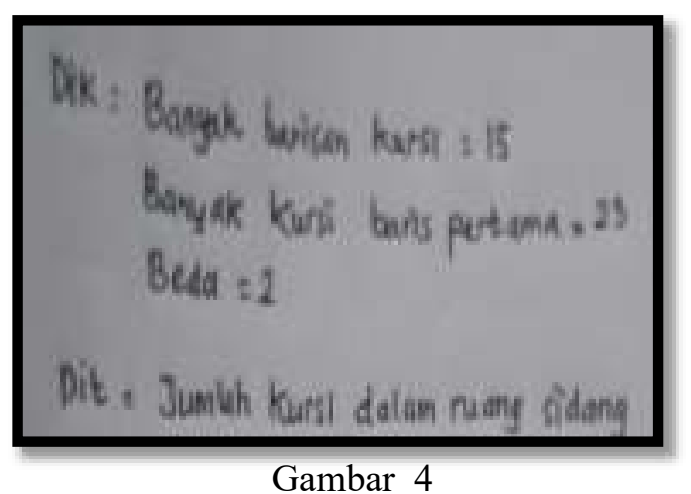

2) Hasil analisis data profil penyusunan rencana pemecahan $\mathrm{M}_{1}$

KIP terlihat agak lebih tenanng walaupun tangannya tidak berhenti bergerak seperti Nampak gelisah dan selalu bertanya pada saat mencari ide memecahkan $\mathrm{M}_{1}$, pada akhirnya KIP mendapat ide rencana untuk memecahkan $\mathrm{M}_{1}$ berdasarkan informasi yang diperolehnya melalui bertanya. KIP mulai tampak gelisah dalam merencanakan penyelesaian $\mathrm{M}_{1}$ karena 


\section{Koordinat Jurnal Pembelajaran Matematika dan Sains}

Vol. 1, No. 1, Juli 2020, Hal. 39-51

ada hal yang masih belum dia ketahui namum ingin jawabannya lengkap. KIP dalam menyusun rencana pemecahan $\mathrm{M}_{1}$ menggunakan rumus yang dia peroleh dari bertanya.

\section{Kutipan 6}

P : Mengapa tadi kamu seperti tidak tenang, terus menerus gelisah

KIP : Bingung saya pak tertukar-tukar pposisi rumusnya yang saya ingat. Seingatku banyak pake tanda kurung rumusnya itu. Bagaimana lagi itu pak?

$\mathrm{P} \quad$ : Ingat, dibutuhkan nilai a di dalam soal berarti banyaknya kursi barisan pertama sebagai nilai a dan beda antara barisan kursi adalah 2 itu sebagai nilai b. coba ingat kembali rumusnya.

KIP : Pertama $S_{n}=n / 2$ baru dikali apa lagi pak? Seingatku ada $n+$ 1 atau $n-1$ ?

$P \quad$ : Coba ingat kembali, $S_{n}=n / 2(2 a$ $+\ldots$...) (sambil diucapkan)
KIP : Ooh iya pak, sambungannya $\mathrm{n}-$ 1 dikali b

3) Hasil analisis data profil pelaksanakan rencana pemecahan $\mathrm{M}_{1}$

KIP melaksanakan apa yang telah direncanakan, yakni menggunakan rumus yang telah ia susun sehingga diperoleh solusi dari masalah $\mathrm{M}_{1}$ yaitu 555. KIP melaksanakan apa yang telah direncanakan dengan terburu-buru serta mengucapkan secara lisan proses pemecahan masalah tertulis tersebut. KIP tampak ingin menyelesaikan dengan segera dalam menyelesaikan masalah $\mathrm{M}_{1}$ karena malas menulis dan lebih menyukai penyampaian secara lisan yang membuat dirinya bersemangat dalam meyelesaikan masalah. Waktu yang diperlukan KIP dalam melaksanakan apa yang telah direncanakan agak lama karena seringkali mengajukan pertanyaan untuk membantunya menemukan solusi dari masalah M1 dan tidak memperhatikan waktu, berikut ini cuplikan hasil pekerjaan KIP.

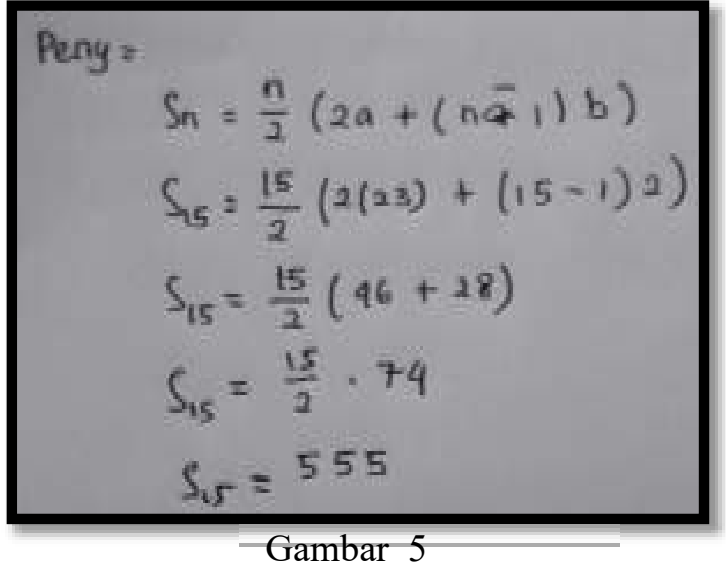

Awalnya KIP kesulitan dalam menyusun rumus untuk memecahkan masalah barisan ini, dengan kecerdasan interpersonalnya, dia secara aktif bertanya sehingga KIP dapat merumuskan dan memperoleh jawaban dari masalah vang di berikan
Berdasarkan hasil observasi dan wawancara terhadap KIP, dapat dideskripsikan bahwa profil pada saat pemeriksaan kembali hasil pekerjaan untuk $\mathrm{M}_{1}$ yaitu KIP melakukan pemeriksaan kembali pada hasil pekerjaannya dengan baik ditandai dengan adanya jawaban akhir yang menjawab pertanyaan dari soal. Berikut 


\begin{tabular}{|c|c|c|c|}
\hline $\begin{array}{l}\text { kutipan } \\
\text { KIP. } \\
\text { Kutipa }\end{array}$ & cuplikan hasil pekerjaar & & $\begin{array}{l}\text { sesuai dengan } \\
\text { diajarkan. }\end{array}$ \\
\hline $\mathrm{P}^{1}$ & $\begin{array}{l}\text { Apakah kamu sudah yakin } \\
\text { dengan hasil jawabanmu? }\end{array}$ & $\mathrm{P}$ & $\begin{array}{l}\text { Jadi, kamu tidak mengecek } \\
\text { hasil pekerjaanmu lagi? }\end{array}$ \\
\hline KIP & $\begin{array}{l}\{\text { melihat lembar jawaban }\} \\
\text { sudah pak. Saya sudah kerja }\end{array}$ & KIP & $\begin{array}{l}\text { (sambil tersenyum) Saya } \\
\text { sudah yakin benar. }\end{array}$ \\
\hline
\end{tabular}

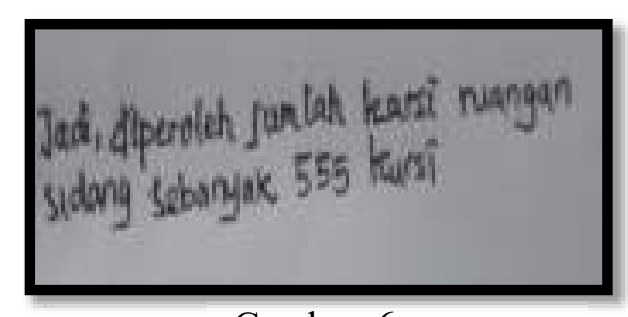

Gambar 6

\section{Profil pemecahan masalah subjek KIL}

(1) Pada saat memahami masalah Barisan dan Deret, subjek KIL membaca masalah tersebut dengan suara keras (dapat terdengan oleh peneliti). Setelah ditelusuri melalui wawancara mendalam ternyata hal tersebut dilakukan untuk memudahkan KIL memahami dan memecahkan soal.Hal ini sesuai dengan yang dikemukakan oleh Hudoyo (Rizal, 2011:27) bahwa suatu soal yang ingin dipecahkan oleh seseorang (termasuk siswa), tetapi cara/langkah untuk memecahkannya tidak segera ditemukan oleh orang itu.

(2) Pada Saat merencanakan pemecahan masalah subjek KIL memiliki rasa kecemasan yang cukup tinggi sebab ketika dia merasa butuh bantuan dia ingin segera bertanya dan dibantu dan terus berfikir mencari ide untuk memecahkan masalah. Pada akhirnya KIL menyusun rencana pemecahan masalah menggunakan rumus deret aritmatika (Sn) dari hasil bebarapa pertanyaan/bantuan dari peneliti dengan pertanyaan yang singkat dan formal.. Hal ini sesuai dengan karakteristik anak yang memiliki kecerdasan interpersonal yang tinggi (Amstrong, 2002) bahwa cara berpikir anak biasanya dengan cara melemparkan gagasan kepada orang lain agar dapat belajar secara optimal dikelas dan dapat menciptakan komunikasi aktif dengan orang lain bukan memikirkan rencana penyelesaian masalah seorang diri sehingga membuatya gelisah dan kurang sabar serta tergesa-gesa.

(3) Ketika melaksanakan perencanaan pemecahan masalah KIL melaksanakan apa yang telah direncanakan yakni menggunakan rumus deret aritmatika (Sn). Pada proses pelaksanaan rencana pemecahan masalah, KIL membutuhkan waktu relative lama. Seperti yang diungkapkan oleh Yaumi (2012) bahwa semakin banyak berhubungan dengan orang lain semakin merasa bahagia, belajar dengan sangat baik ketika berada dalam situasi berinteraksi dengan orang lain. Sehingga dalam menyelesaikan masalah cenderung membutuhkan waktu yang lama disebabkan ingin selalu berdiskusi dengan orang lain.

(4) Berdasarkan hasil observasi dan wawancara terhadap KIL, dapat dideskripsikan bahwa profil pada saat pemeriksaan kembali hasil pekerjaan KIL melakukan pengecakkan kembali dengan baik ditandai dengan KIL menuliskan jawaban akhir dari soal yang diberikan.

\section{Profil pemecahan masalah subjek KIP}

(1) KI membaca masalah tersebut berkali-kali dengan suara agak keras (dapat dingar oleh peneliti) selain itu KIP juga sering mengajukan pertanyaaan untuk mengantarnya memahami masalah. KIP memahami masalah dengan membacanya beberapa kali dan dengan suara keras menunjukkan sikap kurang bergairah dalam menyelesaikan masalah dan kurang merasa senang dalam memahami masalah seorang 


\section{Koordinat Jurnal Pembelajaran Matematika dan Sains Vol. 1, No. 1, Juli 2020, Hal. 39-51}

diri. Ciri-ciri ini sesuai dengan karakteristik orang yang memiliki kecerdasan interpersonal (Yaumi,2012) bahwa orang yang memiliki kecerdasan interpersonal yang tinggi selalu merasa bosan dan tidak bergairah ketika bekerja sendiri serta sangat produktif dan berkembang saat belajar secara kooperatif dan kolaboratif. Siswa yang memiliki kecerdasan interpersonal yang dominan cenderung selalu mengajukan pertanyaan atau mengajak berdiskusi untuk mengantarnya memahami masalah. Karekteristik ini juga merupakan ciri-ciri orang yang memiliki kecerdasan interpersonal (Yaumi,2012) bahwa belajar dengan sangat baik ketika berada dalam situasi yang membangun interaksi antar satu dengan yang lainnya.

(2) KIP dalam merencanakan masalah tampak gelisah pada saat kesulitan menemukan cara meyelesaikan masalah, kurang sabar, tergesa-gesa, dan sering mengajukan pertanyaan untuk membantunya menemukan cara yang tepat dalam menyelesaikan masalah. Pada akhirnya KIP menyusun rencana pemecahan masalah menggunakan rumus deret aritmatika $(\mathrm{Sn})$. Hal ini sesuai dengan karakteristik anak yang memiliki kecerdasan interpersonal yang tinggi (Amstrong, 2002) bahwa cara berpikir anak biasanya dengan cara melemparkan gagasan kepada orang lain agar dapat belajar secara optimal dikelas dan dapat menciptakan komunikasi aktif dengan orang lain bukan memikirkan rencana penyelesaian masalah seorang diri sehingga membuatya gelisah dan kurang sabar serta tergesa-gesa. Selain itu kebutuhan anak yang memiliki kecerdasan interpersonal yang tinggi dalam belajarnya adalah teman-teman, permainan kelompok, pertemuan social dan menyenangi perlombaan sehingga membuatnya gelisah ketika bekerja seorang diri. Siswa yang memiliki kecerdasan interpersonal tinggi juga cenderung ingin berdiskusi dengan seringkali mengajukan beberapa pertanyaan untuk merencanakan pemecahan suatu masalah. Seperti yang diungkapkan oleh Williams (2005) bahwa anak yang memiliki kecerdasan interpersonal yang tinggi lebih suka bekerjasama daripada bekerja sendirian dan menunjukan keterampilan empati dan komunikasi yang baik diruang kelas. Sehingga jika dihadapakan dengan suatu masalah, pasti ingin mencari relasi untuk menyelesaikannya bersama.

(3) KIP dalam melaksanakan perencanaan masalah tampak gelisah, terburu-buru dan lebih menyukai penyampaian lisan dibanding tertulis. Waktu yang digunakan KIP agak lama serta dalam melaksanakan perencanaan pemecahan masalah KIP melaksanakan apa yang telah direncanakan yakni menggunakan rumus deret aritmatika (Sn). Durasi waktu yang digunakan siswa yang memiliki kecerdasan interpersonal yang tinggi dalam melaksanakan rencana pemecahan masalah agak lama. Seperti yang diungkapkan oleh Yaumi (2012) bahwa semakin banyak berhubungan dengan orang lain semakin merasa bahagia, belajar dengan sangat baik ketika berada dalam situasi berinteraksi dengan orang lain. Sehingga dalam menyelesaikan masalah cenderung membutuhkan waktu yang lama disebabkan ingin selalu berdiskusi dengan orang lain.

(4) KIP melakukan pemeriksaan kembali dengan pembuktian hanya sekali dan sering bertanya serta selalu berkata telah yakin dengan jawabannya karena menghindari untuk membuktikan secara tertulis. Hal ini sesuai dengan karakteristik anak dengan kecerdasan interpersonal tinggi (Yaumi, 2012) yang biasanya selalu merasa bosan dan tidak bergairah ketika bekerja sendiri sehingga membutuhkan orang lain untuk lawan berbicara dan berdiskusi tentang pemeriksaan hasil pekerjaan yang diperolehnya. Benny (2012) juga mengatakan bahwa anak dengan kecerdasan interpersonal tinggi mampu berkomunikasi dengan baik secara verbal dan selalu melakukan komunikasi dan berinteraksi dengan orang lain untuk menyelesaikan suatu masalah.

\section{KESIMPULAN}

Berdasarkan hasil penelitian dan pembahasan diperoleh kesimpulan sebagai berikut: (1) Profil pemahaman masalah 


\section{Koordinat Jurnal Pembelajaran Matematika dan Sains}

Vol. 1, No. 1, Juli 2020, Hal. 39-51

matematika subjek KIP yaitu melakukan pembacaan sekali untuk memahami masalah dan dapat mengidentifikasi informasi yang ada pada masalah. (2) Profil pemahaman masalah matematika subjek KIP yaitu melakukan pembacaan berulang-ulang dan membangun interaksi dengan orang lain agar mudah memahami masalah serta dapat mengidentifikasi informasi-informasi yang ada pada masalah. (3) Profil perencanaan pemecahan masalah matematika subjek KIP yaitu menyusun rencana pemecahan masalah menggunakan rumus deret aritmatika serta dapat menuliskan informasi dengan benar apa yang diketahui dan apa yang ditanyakan dari masalah serta dapat meyakini dengan apa yang sudah dia yakini kebenarannya (4) Profil perencanaan pemecahan masalah matematika subjek KIP yaitu menyusun rencana pemecahan masalah menggunakan rumus deret aritmatika serta dapat menuliskan informasi yang benar dari apa yang diketahui pada masalah dengan selalu membangun interaksi dengan orang lain untuk mendiskusikan bersama rencana penyelesaian masalah hanya saja KIP memiliki sifat keragu-raguan cukup tinggi. Hal yang sudah dia tanyakan bisa berulangulang untuk meyakinkan kebenaran sesuatu yang ia tanyakan. (5) Profil pelaksanaan rencana pemecahan masalah subjek KIL yaitu melaksanakan apa yang telah direncanakan yakni menggunakan rumus deret aritmatika (Sn). KA cenderung lebih tenang, tak banyak mengeluarkan kata-kata lagi ketika sudah bertanya dan dia anggap sudah benar langkah yang dia ambil dan KIL juga membutuhkan waktu yang relative lama serta pelaksanaan penyelesaian masalah sesuai dengan rencana yang telah direncanakan sebelumnya. (6) Profil pelaksanaan rencana pemecahan masalah subjek KIP yaitu melaksanakan apa yang telah direncanakan yakni menggunakan rumus deret aritmatika. KI cenderung gelisah, terburu-buru dan membutuhkan waktu yang agak lama. (7) Profil pemeriksaan kembali jawaban subjek KIL melakukan pengecakkan melalui pembuktian sekali merasa yakin dengan jawabannya. (8) Profil pemeriksaan kembali jawaban subjek KIP melakukan pemeriksaan kembali dengan baik ditandai dengan menuliskan kembali jawaban akhir dan sering bertanya serta selalu berkata telah yakin dengan jawabannya.

\section{DAFTAR PUSTAKA}

Armstrong, Thomas. 2002. 7 Kind Of Smart (Menemukan dan Meningkatkan Kecerdasan Anda berdasarka Teori Multiple Intelegence). Jakarta: Gramedia Pustaka Utama

Benny, H. dkk. 2011. Konseling Kelompok Kognitif Spiritual dan Penyesuaian Diri Mahasiswa Difabel Tunanetra.Vol. 02, No. 01, 165-175

Effendi, L.A. (2012). Pembelajan Matematika dengan Metode Penemuan untuk Meningkatkan Kemampuan Representasi dan Pemecahan masalah Matematis Siswa SMP. Jurnal Penelitian Pendidikan.13, (2).

Gardner, H. 2013. Multiple Intelligences, Memaksimalkan Potensi \& Kecerdasan Individu dari Masa Kanak-kanak Hingga Dewasa. Terjemahan Zaimur Y.A Jakarta: Daras Books.

Geary, D. C. et.all. 2000. Sex Differences in Spatial Cognition, Computational Fluency, and Arithmetical Reasoning. Journal of Experimental Child Psychology, 77: 337-353.

Goodchild, S. \& Granholm, B. 2007. An Exploratory Study of Mathematics Result: Wh at is the Gender Effect?. International Journal of Science and Mathematics Education, 7: 161-182

Hardiani, N. 2007. Hubungan antara Kecerdasan Majemuk (Multiple Intelligences) dengan Hasil Belajar Matematika dan Kecenderungan Kesalahan Siswa Kelas X SMU Negeri 1 Pamekasan pada Pokok Bahasan Trigonometri. Tesis, tidak diterbitkan. Malang: Universitas Negeri Malang.

Hudoyo, H. 2005. Pengembangan Kurikulum dan Pembelajaran Matematika. Malang: Universitas Negeri Malang. 


\section{Koordinat Jurnal Pembelajaran Matematika dan Sains}

Vol. 1, No. 1, Juli 2020, Hal. 39-51

Jayantika, T.,Ardana, M. dan Sudiarta, G. P. 2013. "Kontribusi Bakat Numerik, Kecerdasan Spasial dan Kecerdasan Logis Matematis terhadap Prestasi Belajar Matematika Siswa SD Negeri di Kabupaten Buleleng". EJournal PPs. Universitas Pendidikan Ganesha Vol.2. Melalui http://pasca.undiksha.ac.id/ejournal/index.php/JPM/article/view/9 $\underline{81 / 732[23 / 10 / 15]}$

Nafi'an, M.I .2011. Kemampuan Siswa Dalam Menyelesaikan Soal Cerita Ditinjau Dari Gender Di Sekolah Dasar. Yuwono

Nur, Muhammad. Retno.Wikandari, Prima dan Sugiarto, Bambang. 2004. TeoriTeori Pembelajaran Kognitif Edisi 2. Surabaya: Universitas Negeri Surabaya Pusat Sains dan Matematika Sekolah.

Rizal, Muh. 2011. Proses Berpikir Siswa Sekolah Dasar Melakukan Estimasi dalam Pemecahan Masalah Berhitung Ditinjau Dari Kemampuan Matematika dan jenis Kelamin. Disertasi tidak diterbitkan. Surabaya: Universitas Negeri Surabaya

Uno, Hamzah B. 2006. Orientasi Baru Dalam Psikologi Pembelajaran. Jakarta: Bumi Aksara.

Wardani, Asizah Kurnia. 2014. Kemampuan Pemecahan Masalah Berdasarkan Perbedaan Jenis Kelamin ( Ability Of Problem Solving From Diferences Of Sex )Jurnal Pendidikan Matematika STKIP PGRI Sidoarjo.

Williams, S. K. \& Kelly, F. D. (2005). Relationships among involvement, attachment, and behavioral problems in adolescence:examining father's influence. Journal of Early Adolescence, 25, 168-196.

Winarto, P. 2010. Maximizing Your Talent, Menemukan \& Memaksimalkan Potensi Diri Anda. Jakarta: Libri PT. BPK Gunung Mulia.

Yaumi, M. 2012. Pembelajaran Berbasis Multiple Intelligences. Cetakan pertama. Jakarta: PT. Dian Rakyat. 